\title{
BLUEBERRY PRODUCTION IN CHILE: CURRENT STATUS AND FUTURE DEVELOPMENTS ${ }^{1}$
}

\author{
JORGE B. RETAMALES 2 , MARÍA J. PALMA², YOHANNA A. MORALES², \\ GUSTAVO A. LOBOS ${ }^{2}$, CLAUDIA E. MOGGIA², CARLOS A. MENA²
}

\begin{abstract}
Chile has become a major actor in the blueberry industry as the most important supplier of off-season fresh fruit for the northern hemisphere. Blueberry exports passed from US\$ 30 million (around 4,000 tons) in 2000 to US\$ 380 million (94,000 tons) in 2011. The characteristics of the major blueberry growing regions (North, Central, South-central and South) are presented in terms of acreage, varieties, management practices, extension of the harvest season, and soil and climatic conditions. Most fruit is from highbush varieties, picked by hand and exported fresh by boat to United States. Largest proportion of fruit is exported from mid December to late January, which coincides with lowest prices. The south-central region (latitudes $34^{\circ} 50^{\prime}$ to $38^{\circ} 15^{\prime} \mathrm{S}$ ) was in 2007 the most important one with 5,075 ha (51.1\% of area planted). Among the challenges for the Chilean blueberry industry in the near future are: 1 . Lower profitability due to lower rates of currency exchange and higher costs, 2 - Greater scarcity and higher cost of labor, 3.- Need for higher productivity and sustainable production practices, 4- Fruit of high and consistent quality, and 5.Greater investment in research. As a case study the article presents three approaches that can help identify areas with low availability of labor and improve its efficiency. The article shows the use of geomatic tools to establish labor availability, application of growth regulators to reduce crop load, increase fruit size and improve harvest efficiency, and the use of shakers to harvest fresh fruit for long distance markets. More research is needed to improve yields, reduce costs and give greater economical and ecological sustainability to the Chilean blueberry industry.
\end{abstract}

Index terms: Biotechnology, growth regulator and plant science.

\section{PRODUÇÃO DE MIRTILO NO CHILE: SITUAÇÃO ATUAL E DESENVOLVIMENTOS FUTUROS}

RESUMO - O Chile tornou-se de grande atuação na indústria de Mirtilo como o fornecedor mais importante de frutas frescas de entressafra para o hemisfério Norte. Exportações de Mirtilo passaram de \$30 milhões de dólares americanos (cerca de 4.000 toneladas) em 2000, para 380 milhões (94 mil toneladas) em 2011. As características das principais regiões de cultivo de Mirtilo (Norte, Central, Centro-Sul e Sul) são apresentados em termos de área plantada, variedades, práticas de manejo, extensão do período de colheita, e condições climáticas e do solo. A maioria das frutas é de variedades highbush, colhidas à mão e exportados frescas para os Estados Unidos por barco.Grande porcentagem do fruto é exportada a partir de meados de dezembro até o final de janeiro, que coincide com preços mais baixos. A região Centro-sul (latitude $34^{\circ} 50^{\circ}$ a $38^{\circ} 15^{\prime}$ S), foi em 2007 a mais importante, com 5.075 ha (51,1\% da área plantada). Entre os desafios da indústria de Mirtilo no Chile em um futuro próximo são: 1. Baixa rentabilidade devido à diminuição das taxas de câmbio e custos mais altos, 2. Maior escassez e aumento do custo da mão-de-obra, 3 . Necessidade de uma maior produtividade e práticas de produção sustentável, 4. Fruta de alta e consistente qualidade, e 5. Maior investimento em pesquisa. Como estudo de caso o artigo apresenta três abordagens que podem ajudar a identificar as áreas com baixa disponibilidade de mão de obra e melhorar a sua eficiência. O artigo mostra o uso de ferramentas de geomática para estabelecer a disponibilidade de mão-de-obra, a aplicação de reguladores de crescimento para reduzir a carga das culturas, aumentar o tamanho dos frutos e melhorar a eficiência da colheita, bem como a utilização de sacudidores para colher frutas frescas para os mercados de longa distância. Mais pesquisas são necessárias para melhorar o rendimento, reduzir custos e dar maior sustentabilidade econômica e ecológica para a indústria de Mirtilo do Chile.

Termos para indexação: biotecnologia, regulador de crescimento e fitotecnia.

${ }^{1}$ (Trabalho 446-13). Recebido em: 20-09-2013. Aceito para publicação em: 15-12-2013. Palestra II Simpósio Internacional de Fruticultura- Frutas Exóticas, 21 a 25 de outubro de 2013. Jaboticabal-SP.

${ }^{2}$ Centro de Mejoramiento Genético y Fenómica Vegetal, Universidad de Talca.

${ }^{2}$ Centro de Geomática, Universidad de Talca. 


\section{INTRODUCTION}

Chile stretches for over 4,000 km along the southwest coast of South America. The Andes mountains located on the east side of the country provide irrigation water for the most important fruit producing regions in the country. The lower altitude coastal range is located on the west. Between these two mountain ranges is a long central valley where most Chilean fruit is grown. The large continuum in altitude and latitude provides Chile with diverse climates suitable for growing a wide range of fruit crops (Hancock et al., 1992).

As with other fruit crops, Chile has become an important producer and exporter of blueberries. Currently, the largest area of blueberries in the world resides in Chile, exceeding Michigan and British Columbia by 23 and $33 \%$, respectively (Retamales and Hancock, 2012). Cultivated blueberries (highbush and rabbiteye) not only have expanded in Chile but have become a major international crop, with about 40,500 hectares planted in North America, 16,200 in South America (of which around 10,000 ha are planted in Chile), 7,300 in Europe, 2,000 in China and Japan, and 1,200 in Australia and New Zealand (Brazelton, 2009). Overall, annual world production of highbush and rabbiteye now exceeds 300 metric tons. Of this total, nearly $75 \%$ is northern highbush, $10 \%$ southern highbush and $15 \%$ rabbiteye (Retamales and Hancock, 2012).

The first commercial blueberry plantings were made in Chile in the late 1980s. Highbush and rabbiteye plants of different varieties were brought from USA and New Zealand by INIA (National Agricultural Research Institute) and the Universidad Austral in the late 1970s to be studied as new options for expanding the fruit industry. Even though commercial plantings started in 1985, the largest development occurred in Chile from 1997 (Bañados, 2006). Blueberries were first planted in southern Chile (latitudes $36^{\circ}$ to $42^{\circ} \mathrm{S}$ ), but the high prices for blueberries in October and November lead in the late 90s to several plantations of low-chill SHB cultivars in northern latitudes (Bañados, 2006; Lyrene and Muñoz, 1997). In 1992 a total of 280 ha were estimated to be planted, most of them in the southern region (Hancock et al., 1992). By 2003, there were 2,135 ha of blueberries in Chile. From 2003 to 2007, the growth rate accelerated, reaching $9,940$ ha by 2007 (+ $466 \%)$. Most of the recent expansion (2003-2007 period) has occurred in the central (668\%) and south-central regions (804\%), while the early (north) and late (south) producing regions have expanded at a relatively slower rate
(Table 1).The rate of expansion has decreased in the last years mainly due to lower fruit prices and higher harvest costs due to reduced labor availability.

\section{Climatic and soil conditions of Chilean production regions.}

Chile is divided into political regions. Regions are numbered starting with the lowest number in the north (lower latitudes); the Metropolitan Region of Santiago, the capital city is denominated as RM (Bañados, 2006) (Figure 1).

Northern region (latitudes: $29^{\circ}$ to $33^{\circ} 10^{\prime}$ ). In Chile the early ripening table grapes are traditionally produced in this area. This zone amounted in 2007 to $3.6 \%$ of total area planted to blueberries in Chile (Table 1). Soils have alkaline $\mathrm{pH}$ and some salinity, soil textures are medium to heavy. Waters have high contents of carbonates and sometimes high salinity. Climate is temperate semi-arid, with low number of chilling hours (50 to 500, depending on latitude and elevation) (Bañados, 2006). Annual rainfall is lower than $250 \mathrm{~mm}$, concentrated in winter.

Central region (latitudes: $33^{\circ} 10^{\prime}$ to $34^{\circ} 50^{\prime}$ ). This area is where the most important traditional fruit crops are grown in Chile (Bañados, 2006). In 2007 this region amounted for $11.5 \%$ of total Chilean blueberry acreage (Table 1). Soils have alkaline $\mathrm{pH}$ and some salinity, textures are medium to heavy. Waters have no salinity but some may have low levels of carbonates. The climate is temperate semi-arid, with 400-1,000 chilling hours. The area receives $300-450 \mathrm{~mm}$ rainfall concentrated in winter.

South-Central Region (latitudes: $34^{\circ} 50^{\prime}$ to $\left.38^{\circ} 15^{\prime}\right)$. This area is the most important blueberry producing region in the country $(51.1 \%$ of total acreage in 2007; Table 1). Is characterized by excellent conditions to grow blueberries and where the highest yields of the country are usually obtained (Bañados, 2006). Soils with neutral pH and medium to heavy textures predominate. Good quality waters (no salts or carbonates) are used. The zone has a temperate climate with 800 to 1,500 chilling hours. The rainfall $(500-800 \mathrm{~mm})$ is concentrated in winter and early spring.

South Region (latitudes: $38^{\circ} 15^{\prime}$ to $43^{\circ} 40^{\prime}$ ). This zone of the country is where the blueberry industry developed first. In 2001 represented over $50 \%$ of the planted area but by 2007 decreased to almost $40 \%$ of total area planted (Table 1). Soils have volcanic origin and acid $\mathrm{pH}$, with medium textures and high organic matter (10\% to $12 \%$; Bañados, 2006). Good quality waters (no salts or carbonates) are available. The climate is temperate with 1,2002,500 chilling $h$ and 1,000-2,000 $\mathrm{mm}$ annual rainfall 
mainly in winter and spring, but often in summer.

\section{Cultural conditions of major Chilean production regions}

There is considerable variation in production systems across the blueberry growing regions. Some common management practices are listed below, while the information for specific zones is provided separately. Plants are usually established on raised beds. Pine chips or sawdust are often used for mulching. Dormant pruning is done annually or biannually by removing the least productive canes; only limited fine pruning in the canopy is employed (Retamales and Hancock, 2012). Trickle irrigation is prevalent although microjet irrigation is also used. Fertilizer is usually applied through fertigation.

Northern region (latitudes: $29^{\circ}$ to $33^{\circ} 10^{\prime}$ ). Higher density plantings are generally employed in this zone (0.7-0.9 $\mathrm{m}$ within rows and $2.5-3 \mathrm{~m}$ between rows). Plants are commonly set in the fall or early winter. In order to avoid the inadequate soil conditions prominent in this area, some growers have planted in containers. Southern highbush varieties predominate, mainly O'Neal and Misty (Bañados, 2006). Harvest season extends from early October to end of November.

Central region: The most common varieties in this zone are southern highbush, mainly O'Neal as well the early northern highbush Duke, although rabbiteyes are also present (Bañados, 2006). The harvest season extends from mid October to end of November.

South-Central Region (latitudes: $34^{\circ} 50^{\prime}$ to $\left.38^{\circ} 15^{\prime}\right)$. A broader range of cultivars are planted including NHB ('Duke', 'Bluecrop', 'Brigitta' and 'Elliott') and SHB ('O'Neal'), there are also some rabbiteye, mainly 'Brightwell' and 'Tifblue' (Bañados, 2006; Retamales and Hancock, 2012). Fruit harvest extends from the end of November until late January.

South Region (latitudes: $38^{\circ} 15^{\prime}$ to $43^{\circ} 40^{\prime}$ ). Plants are typically planted in the spring at in-row spacings of 1.0 to $1.2 \mathrm{~m}$ and $3 \mathrm{~m}$ between rows. Growers have planted mid to late season northern highbush and rabbiteye varieties (Retamales and Hancock, 2012). The main cultivars are 'Elliott' and 'Brightwell' (Bañados, 2006). The harvest season extends from late January to early March. Shading nets are being tested in this zone of Chile as a means to delay harvest and prevent sunburn of leaves and fruit.

\section{Harvest and Marketing of Chilean Blueberries}

Chile plays a pivotal role in expanding the worldwide blueberry production season. Its location in the southern hemisphere allows blueberries to be grown and shipped to the northern hemisphere during the winter (November through March), when fresh fruit in those latitudes is not available (Beaudry et al., 1998). The key to maintain Chile as a strong player in off-season supply of blueberries is to ship highquality fruit to northern hemisphere countries. To attain this goal, variety, cultural management, harvest and postharvest handling need to be considered (Retamales and Hancock, 2012). In the 90's, when blueberry exports from Chile were starting, most fruit was sent by airplane. The lower cost (about one third) and the delay in fruit arrival (around 3 weeks for USA) of the sea shipment proved advantageous to increase profits and spread out the Chilean peak of production in January. Research done in the mid 90's confirming that high quality fruit would withstand boat freight (Beaudry et al., 1998), had a major impact on the proportion of fruit shipped by boat which now reaches around 95\% (Fig. 2).

The volume of blueberries exported by Chile has increased markedly in the last years, from nearly 3,500 ton in the 1998-99 season to almost 95,000 tons in the 2010-11 season. The relative importance of fruit exported fresh and frozen has changed over time; they grew at a similar pace in the 1998-03 period but the expansion of frozen blueberries was more than $3 x$ the one of fresh fruit in the 2006-07 to 2010-11 period (Table 2). Availability of stocks of frozen blueberries and saturation of markets for fresh fruit in the USA, as well as quality issues and availability of labor for Chilean blueberry growers would explain these changes.

The main market for fresh blueberry from Chile is the USA with $82-85 \%$ of the volume exported in the 2008-2011 period, followed by Europe (1214\%) and Far East (3\%) (Decofrut, 2011). In Chile, there are more than 30 companies that export fresh blueberries. For the 2008/09 season, the largest were Hortifrut-Chile and Vitalberry Marketing, with 18\% and $15 \%$ of the total fresh export volume, respectively (Chile Export Association). The share of the market by these companies has decreased in the last years as it was reported that in the 2003/04 season they had 20 and $23 \%$ of the market, respectively (Bañados, 2006). Due to lower prices and higher costs, there is tendency in mid to large growers create their own exporting companies or to merge in order to export directly. The largest proportion of the fruit is exported from mid December to late January (Figure 3). 


\section{Critical points and challenges for the Chilean blueberry industry}

In the last 25 years, the chilean blueberry industry has expanded at a fast pace. However, as in other fruit exporting sectors, fruit production and export is facing difficulties that have reduced the profitability and are putting at risk the viability of blueberry operations in Chile. In this context, there are several challenges that have to be faced by the Chilean blueberry industry (Retamales and Sepúlveda, 2011):

1.- Reduced profitability due to lower rates of currency exchange which in the last ten years has drop by $33 \%$ (FEDEFRUTA, 2011), as well as rising costs of energy. Oil price in 2010 was $4 \mathrm{x}$ higher than in 2001, while electricity was $3.1 \mathrm{x}$ higher in 2010 than in 2004.

2.- Greater scarcity and higher cost of labor. Labor accounts for $40-70 \%$ of the cost of producing blueberries in Chile. Mechanization reduces labor needs (Retamales and Hancock, 2012). Since Chile is focused on fresh fruit export, mechanical harvesting is generally not compatible with adequate postharvest life and condition of the fruit upon arrival to the markets.

3.- Higher productivity and sustainable production practices: Precision agriculture and improved irrigation and fertilization practices should reduce costs and improve sustainability. The market is increasingly demanding sustainable production practices. Growers are aware of this and are advancing in various ways (Retamales and Sepúlveda, 2011).

4.- Fruit of high and consistent quality: In order to absorb the greater production, there is a need to attract new customers. With higher expansion in fruit volumes than in its demand, purchasers will request higher fruit quality. Also, as Chile increases the proportion of fruit shipped to long distance markets, fruit quality will become more heterogeneous and this will become a major challenge for the Chilean blueberry industry (Moggia et al., 2009).

5.- Greater investment in research and innovation. Chile invests only $0.7 \%$ of its GDP in science and research (Retamales and Sepúlveda, 2011). Local research has been done for more than 20 years, and has helped growers to solve their problems. However a closer relationship between researchers and the private industry is still needed to address and solve various local production problems (Bañados, 2006). The number of researchers and projects on blueberries has expanded at a much lower rate than the size and complexity of the industry.

Case study on research in blueberries: labor efficiency and availability for harvest

Scarcity of labor can negatively impact on the expansion of the Chilean blueberry industry. Harvest is the operation that uses the highest proportion of labor (Retamales and Hancock, 2012). In this chapter we present three approaches to improve the efficiency and/or predict the availability of labor for blueberry harvest.

Typical yields in Chile are 8 to $10 \mathrm{t}$ ha- 1 , but they vary depending on plant age, cultivar management practices and region. Fruit for fresh market are picked by hand (Retamales and Hancock, 2012).

1.- Use of growth regulators increase fruit size and improve harvest efficiency: Experiments done on highbush 'Bluecrop' plants (Table 3), showed that two GA3 (gibberellic acid) applications of $300 \mathrm{ppm}$ done 15 and 18 weeks after full bloom markedly reduced fruit number $(45 \%$ less than non-sprayed control) in the following season and significantly improved fruit size (38\% greater than control) (Retamales and Hancock, 2012). Yields were $30 \%$ lower, but the greater size might prove advantageous for growers who are focused on hand picking for fresh market, since both harvest efficiency (Strik et al., 2003) and fruit price should be improved.

2.- Effect of different types and times of harvest on the quality of fresh blueberries: The purpose of this trial was to evaluate options that would improve labor efficiency without damaging fruit quality. The trial done in ten-year-old commercial plantings cv. Brigitta and O'Neal had 6 treatments, which combined 3 types of harvest (hand, automotive or shaker) with two times of harvest (morning: AM or afternoon: PM). AM harvest had greatest fruit firmness, independent of cv. and harvest type. In the initial evaluation (at harvest) there were no differences in firmness between hand PM and shaker PM. Among harvest types, hand picking had the highest firmness, followed by shaker and automotive (Table 4). The automotive equipment required the least labor and the shaker was intermediate. Labor required to harvest $\mathrm{O}^{\prime} \mathrm{Neal}$ nearly doubled the requirements for Brigitta (Table 5). Shakers appear as a good alternative considering that fruit quality is similar to hand-picked fruit and that the cost of the equipment is much lower that 
the automotive equipment. There is much room for improvement in the use of shakers by growers.

\section{region:}

\section{3.- Availability of labor within the Maule}

As exposed previously, the Maule region is one of the most important blueberry-producing areas in Chile. Optimal soil and climatic conditions have concentrated the planting in certain counties of the region (Figure 4). The map shows that currently there is a high concentration of plantings in some counties located in the southern border of the Maule region (Parral, Retiro) where the potential availability of labor is low. Even though growing conditions would be appropriate and potential yields would be high, further blueberry plantings in that area would face problems with availability (and cost) of labor especially at harvest time (Retamales and Sepúlveda, 2011).

TABLE 1- Evolution (2001-2007) of area planted with blueberries in different regions of Chile. Source: ODEPA, 2007

\begin{tabular}{|c|c|c|c|c|c|}
\hline \multirow{2}{*}{$\begin{array}{l}\text { Latitude/Year } \\
\text { Rate of Increment }\end{array}$} & \multicolumn{5}{|c|}{ Area planted with blueberries in different regions (ha) } \\
\hline & North & Central & South-Central & South & Total \\
\hline Latitude South & $29^{\circ}$ to $33^{\circ} 10^{\prime}$ & $33^{\circ} 10^{\prime}$ to $34^{\circ} 50^{\prime}$ & $34^{\circ} 50^{\prime}$ to $38^{\circ} 15$ & $38^{\circ} 15^{\prime}$ to $43^{\circ} 40$ & $29^{\circ}$ to $43^{\circ} 40$ \\
\hline $2001(\%$ of total $)$ & $62(3.3)$ & $170(8.9)$ & $631(33.0)$ & $1,047(54.8)$ & 1,910 \\
\hline $2007(\%$ of total $)$ & $355(3.6)$ & $1,136(11.5)$ & $5,075(51.1)$ & $3,956(39.8)$ & 9,940 \\
\hline$\Delta: 2001-2007$ (ha) & 293 & 966 & 4,444 & 2,909 & 8,030 \\
\hline$\Delta: 2001-2007(\%)$ & 572 & 668 & 804 & 378 & 520 \\
\hline
\end{tabular}

TABLE 2- Evolution of blueberry volumes exported by Chile (fresh, frozen, total) for the period 19982011 and increment in 1998-99 to 2002-03 and 2006-07 to 2010-11.

\begin{tabular}{|l|c|c|c|c|}
\hline \multirow{2}{*}{ Exporting season } & $\begin{array}{c}\text { Value exported per season } \\
\text { (MUS\$) }\end{array}$ & \multicolumn{3}{|c|}{$\begin{array}{c}\text { Volume exported per season } \\
\text { (metric tons) }\end{array}$} \\
\cline { 2 - 5 } & Fresh (FOB) & Fresh & Frozen & Total \\
\hline $1998-1999^{\mathrm{z}}$ & 22,700 & 3,126 & 313 & 3,439 \\
\hline $2002-2003^{\mathrm{z}}$ & 46,600 & 5,298 & 544 & 5,842 \\
\hline $2006-2007^{\mathrm{y}}$ & 143,900 & 21,150 & 2,200 & 23,350 \\
\hline $2010-2011^{\mathrm{x}}$ & 380,000 & 68,376 & 25,000 & 93,376 \\
\hline$\Delta: 1998-99$ to $2002-03$ & $2.1 \mathrm{x}$ & $1.7 \mathrm{x}$ & $1.7 \mathrm{x}$ & ---- \\
\hline$\Delta: 2006-07$ to $2010-11$ & $2.6 \mathrm{x}$ & $3.0 \mathrm{x}$ & $10.0 \mathrm{x}$ & ---- \\
\hline
\end{tabular}

Sources: ${ }^{\mathrm{B}}$ Bañados, 2006; ${ }^{\mathrm{y}}$ Navarrete et al., 2010; ${ }^{\mathrm{x}}$ Decofrut, 2011 and 2012.

TABLE 3 -Effect of the number of applications ${ }^{2}$ of $\mathrm{GA}_{3}(300 \mathrm{ppm})$ on buds per shoot, and the number and weight of fruit at harvest in 4-year-old 'Bluecrop' highbush blueberries growing in Collipulli (Lat. $38^{\circ} \mathrm{S}$; Chile). Source: Retamales et al., 2000

\begin{tabular}{|c|c|c|c|}
\hline \multirow{2}{*}{ GA $_{3}$ sprays (no.) } & \multirow{2}{*}{ Buds/shoot (no.) } & \multicolumn{2}{|c|}{ Fruit at harvest $^{\mathrm{w}}$} \\
\cline { 3 - 4 } & & Number & Weight/fruit $(\mathrm{g})^{\mathrm{N}}$ \\
\hline 0 & $16.6 \mathrm{a}$ & $606 \mathrm{~b}$ & $1.3 \mathrm{a}$ \\
\hline 1 & $15.7 \mathrm{a}$ & ---- & ---- \\
\hline 2 & $17.7 \mathrm{a}$ & $332 \mathrm{a}$ & $1.8 \mathrm{~b}$ \\
\hline
\end{tabular}

${ }^{z}$ Applications done 15 and 18 weeks after full bloom.

${ }^{y}$ Means followed by the same letter within columns are not significantly different, LSD, $p<0.01$

${ }^{x}$ Measured on October 16, 1996

${ }^{\mathrm{w}}$ Measured between December 17, 1996 and January 16, 1997. 
TABLE 4 - Effect of harvest hour (AM or PM) and harvest type (hand, automotive or shaker) on fruit firmness of $\mathrm{O}^{\prime} \mathrm{Neal}$ fruit at harvest or postharvest ( 45 or 60 days at $1^{\circ} \mathrm{C}$ plus $1 \mathrm{~d}$ at $18^{\circ} \mathrm{C}$ ).

\begin{tabular}{|l|c|c|c|c|}
\hline \multirow{2}{*}{ Variable } & \multirow{2}{*}{ Item } & \multicolumn{3}{|c|}{ Firmness $(\mathrm{g} \mathrm{mm}-1)$} \\
\cline { 3 - 5 } \multirow{2}{*}{ Hour } & AM & $180.4 \mathrm{a}$ & 158.7 & $126.0 \mathrm{a}$ \\
\hline \multirow{2}{*}{ Significance } & PM & $170.6 \mathrm{~b}$ & 157.3 & $118.1 \mathrm{~b}$ \\
\hline Type & $\mathrm{p}$ value & 0.0000 & 0.6055 & 0.0020 \\
\hline & Hand & $199.6 \mathrm{a}$ & $170.5 \mathrm{a}$ & $125.7 \mathrm{a}$ \\
\hline & Automotive & $129.6 \mathrm{~b}$ & $140.0 \mathrm{~b}$ & $109.8 \mathrm{~b}$ \\
\hline Significance & Shaker & $197.1 \mathrm{a}$ & $163.4 \mathrm{a}$ & $130.5 \mathrm{a}$ \\
\hline Hour $\mathbf{x}$ Type & p value & 0.0000 & 0.0000 & 0.0000 \\
\hline AM & & & & \\
\hline & Hand & $214.2 \mathrm{a}$ & 175.5 & 130.9 \\
\hline & Automotive & $124.2 \mathrm{e}$ & 138.5 & 110.4 \\
\hline PM & Shaker & $202.7 \mathrm{~b}$ & 162.0 & 136.6 \\
\hline & Hand & $185.0 \mathrm{c}$ & 165.6 & 120.5 \\
\hline & Automotive & $135.1 \mathrm{~d}$ & 141.6 & 109.3 \\
\hline Significance & Shaker & $191.6 \mathrm{c}$ & 164.7 & 124.5 \\
\hline
\end{tabular}

Averages within a column followed by the same letter within a factor, do not differ statistically (HSD at $\mathrm{p}=0.05$ ).

TABLE 5- Number of working days ( 8 hours/day) used per hectare for each type of harvest for mature plants of two highbush blueberry cultivars.

\begin{tabular}{|c|c|c|}
\hline \multirow{2}{*}{ Type of harvest } & \multicolumn{2}{|c|}{ Number of working days /ha* } \\
\cline { 2 - 3 } & O'Neal & Brigitta \\
\hline Hand & 105 & 55 \\
\hline Automotive & 3 & 2 \\
\hline Shaker & 61 & 30 \\
\hline
\end{tabular}

*Data calculated from field measurements (time needed to harvest, number of people, and number of harvested plants) 


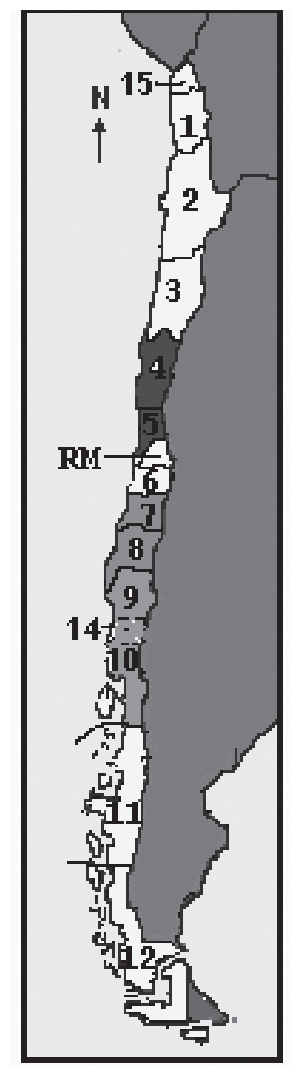

FIGURE 1-Blueberry producing regions in Chile. Areas indicated with numbers 4 and 5 conform the north Region (blue background), those with 6 and RM correspond to the Central region (yellow background), the ones with 7 and 8 are part of the South-Central Region (red background), finally the south region (purple background) includes regions numbered 9, 10 and 14 .

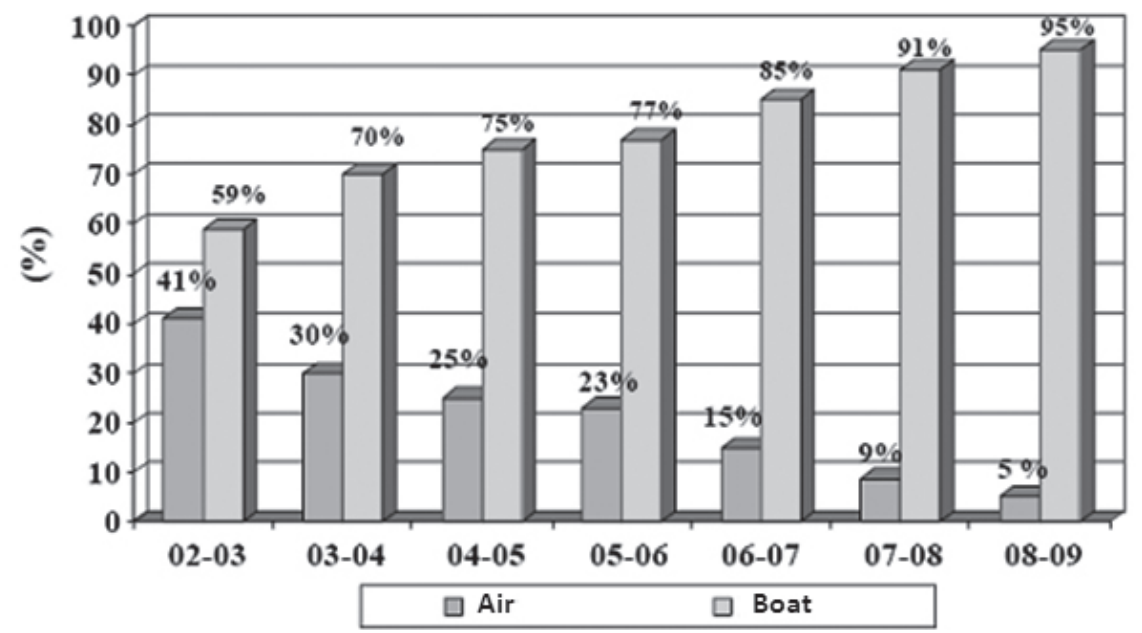

FIGURE 2- Evolution of the proportions (\%) of fresh blueberries exported by Chile via airplane or boat in the 2003-2004 to 2008- 2009-2010 seasons. Source: Comité de Arándanos, 2011. 


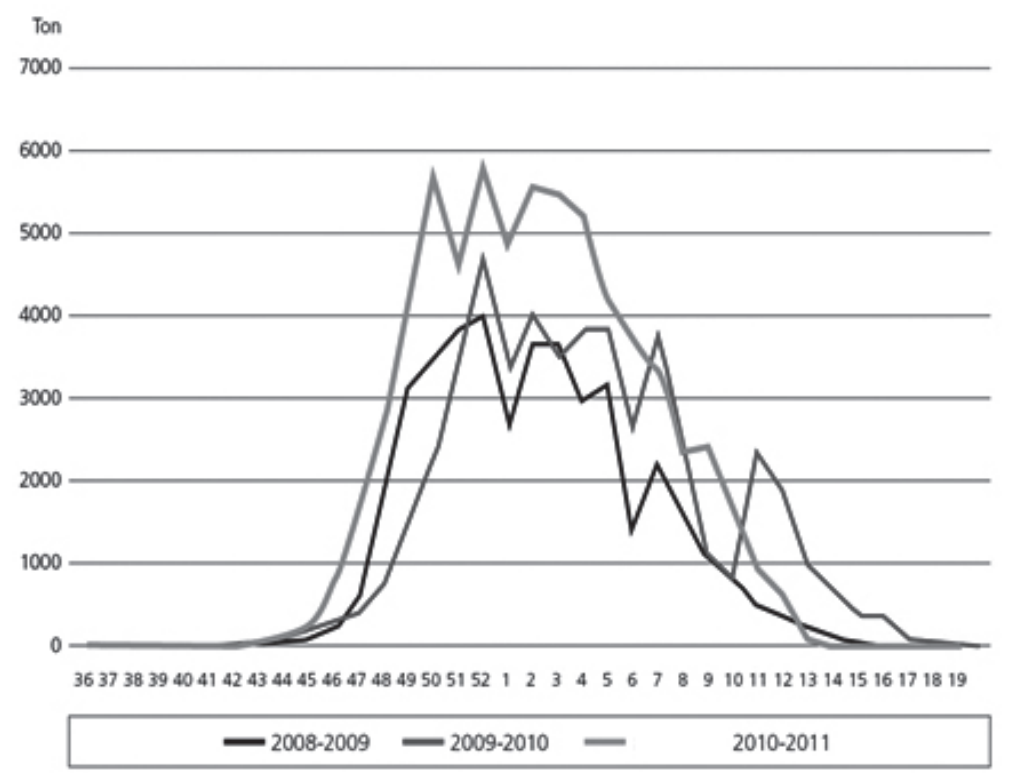

FIGURE 3- Weekly volumes (tons) of fresh blueberries exported by Chile in the 2008-09, 2009-10 and 2010-11 seasons. Source: Comité de arándanos, 2011.

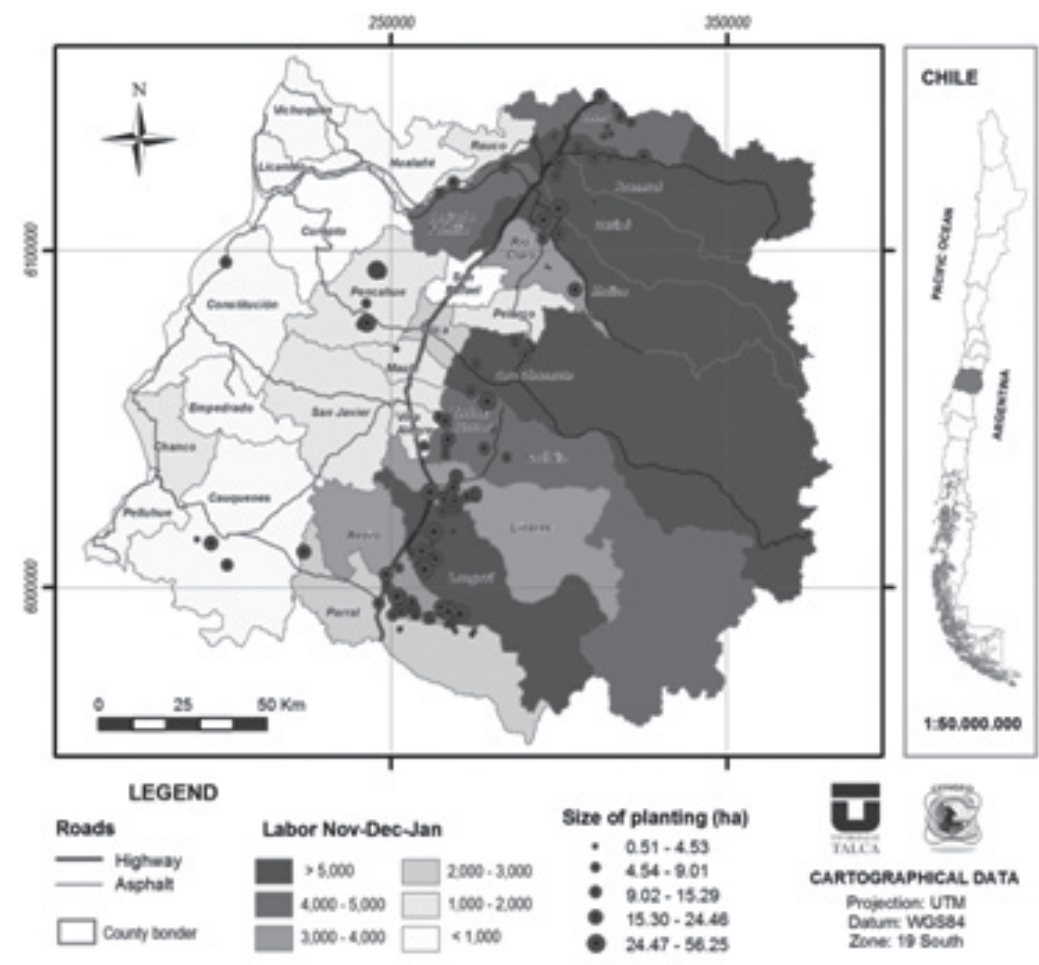

FIGURE 4- Seasonal labor availability and size of blueberry plantings in the different counties of the Maule Region. 


\section{CONCLUSIONS}

Since blueberries were introduced in the late eighties, Chile has become the most important producer and exporter of this fruit in the southern hemisphere. In 2011 exports reached US\$ 380 million (94,000 tons), of which over $70 \%$ was exported as fresh fruit. According to geographical location, four major blueberry growing regions can be established (North, Central, South-central and South). They have a large range of soil and climatic conditions, as well as management practices and varieties used. The south-central region (extending from latitudes $34^{\circ} 50^{\prime}$ to $38^{\circ} 15^{\prime} \mathrm{S}$ ) was in 2007 the most important one with 5,075 ha $(51.1 \%$ of area planted). Most blueberry fruit produced by Chile is from highbush varieties, picked by hand and exported fresh by boat to United States. The greatest percentage of fruit is exported in the mid December to late January period, which coincides with lowest prices in the off-season. The Chilean blueberry industry will face various challenges in the near future, such as: 1 .- excess fruit offer, 2.- lower currency exchange rates, 3.- higher production costs (labor, energy, etc.), 4.- lower availability and higher cost of labor, 5.- need for greater production efficiency and more sustainable agricultural practices, 6.- high and consistent fruit quality, and 7.- greater investment and scope of research activities. The article approached the case of labor for fruit harvest; through geomatic tools the labor availability in different counties of the Maule region can be defined, also the efficiency of labor at harvest can be improved by reducing crop load (and enlarging fruit size) through the application of growth regulators, while the picking efficiency can be increased with the use of shakers to harvest fresh fruit for long distance markets. More research is needed to improve yields, reduce costs, improve fruit quality and provide greater economical and ecological sustainability to the Chilean blueberry industry.

\section{ACKNOWLEDGEMENTS}

Partial financing for this research provided by projects FONDEF D09R1008 and INNOVA-CORFO $11 \mathrm{BPC}-10100$ is appreciated.

\section{REFERENCES}

BAÑADOS, M.P. Blueberry production in South America. Acta Horticulturae, The Hague, v.715, p.165-172, 2006.

BEAUDRY, R.M.; MOGGIA, C.E. ; RETAMALES, J.B.; HANCOCK J.F. Quality of 'Ivanhoe' and 'Bluecrop' blueberry fruit transported by air and sea from Chile to North America. HortScience, Alexandria, v.33, p.313-317, 1998.

BRAZELTON, C. World blueberry acreage and production report. Folsom: United States Highbush Blueberry Council - Industry Relations Committee, 2009.

COMITE DE ARANDANOS. Proyecciones. 2011. Disponível em: <www.comitedearandanos.cl/2010/ spanish/proyeccion $>$.

DECOFRUT. Avance de la temporada de arándanos. Berries \& Cherries, Chile, n.8, p.37-40, 2012.

DECOFRUT. Avance de temporada para cerezos y arándanos. Berries \& Cherries, Chile, n. 13, p.4648, 2012.

FEDEFRUTA. El sector enfrenta su peor crisis de rentabilidad de los últimos 25 años. 2011. Disponível em: $\leq$ www.fedefruta. $\underline{\mathrm{cl} / \text { ?area }=\text { Noticias\&id }=939>}$. Acesso em: 12 maio 2012

HANCOCK, J. F.; RETAMALES, J. B.; LYRENE, P. ; MOGGIA C.; LOLAS, M.. Blueberry culture in Chile: current status, future prospects. HortTechnology, Alexandria, v.2, n.3, p.310-315, 1992.

LYRENE, P.M.; MUÑOZ, C. Blueberry production in Chile. Journal of Small Fruit and Viticulture, Binghamton, v.5, p.1-20, 1997.

MOGGIA, C., RETAMALES, J.B., G.A. LOBOS y P. D.S. CALIGARI. Arándanos en Chile: ¿Un futuro azul o gris? Revista Frutícola, Curico, v.3, p.50-53, 2009.

NAVARRETE, J.; SOTO, C.; JORQUERA, R.; GUERRA, E. Arándanos. Informe Centro de competitividad del Maule, 2010. Disponível em: $<$ www.centrodecompetitividaddelmaule.cl $>$. Acesso em: 9 maio 2012. 
ODEPA. Censo agropecuario. 2007. Disponível em: $\quad<$ www.censoagropecuario.cl/index2.html $>$. Acesso em: 12 maio 2012.

RETAMALES, J.B.; HANSON, E.J.; BUKOVAC, M. J. GA3 as a flowering inhibitor in blueberries. Acta Horticulturae, The Hague, v.527, p.147-152, 2000.

RETAMALES, J.B.; SEPÚLVEDA, J.C. Fruit production in Chile: bright past, uncertain future. Revista Brasileira de Fruticultura, Jaboticabal, v.33, p.173-178, 2011.
RETAMALES, J. B.; HANCOCK, J.F. Blueberries. Oxfordshire: CABI, 2012. 336 p. (Crop Production Science in Horticulture Series)

STRIK B.; BULlER, G.; HELLMAN, E. Pruning severity affects yield, berry weight, and hand harvest efficiency of highbush blueberry. HortScience, Alexandria, v.38, p.196-199, 2003. 